\title{
PELATIHAN GOSOK GIGI YANG BAIK DAN BENAR DI TK AR- RAAFI
}

\author{
Milda Hastuty \\ D III Kebidanan, Fakultas Ilmu Kesehatan, Universitas Pahlawan Tuanku Tambusai \\ email:melda.obie@gmail.com
}

\begin{abstract}
Abstrak
Sekolah TK Ar-Raafi Kecamatan Tambang merupakan salah satu taman kanak-kanak yang berada di Kampar. Berdasarkan data yang didapat terdapat beberapa kendala yang dihadapi TK Ar-Raafi dalam menegakkan disiplin masyarakat sekolah khususnya peserta didik dalam penerapan delapan pola hidup bersih dan sehat di sekolah, diantaranya menggosok gigi yang baik dan benar. Saat ini dalam menjalankan program kegiatan akademiknya belum sepenuhnya di dukung oleh kegiatan yang mengarah pada peningkatan keterampilan dan sikap peserta didik termasuk belum maksimalnya jangkauan pendidikan ekstrakulikuler yang nantinya akan memberikan nilai tambah bagi peserta didik. Data awal didapatkan bahwa gambaran untuk perilaku hidup bersih bagi peserta didik masih dinilai cukup. Kita ketahui bersama sekolah sebagai tempat bagi peserta didik dalam menimba ilmu perlu mengembangkan kegiatan yang berbasis pada kemampuan akademis dan soft skill yang mendukung kegiatan pembelajaran. Pelatihan "Gosok Gigi yang baik dan benar di TK Ar-Raafi" dapat meningkatkan pengetahuan tentang Cara gosok gigi yang benar. Peningkatan pengetahuan dan keterampilan bagi peserta pelatihan tentang cara gosok gigi benar dilakukan dengan metode ceramah dan demonstrasi. Pemberdayaan guru dalam pemantauan gosok gigi diharapkan dapat terwujud dengan baik dengan adanya pemberian beberapa contoh cara gosok gigi yang benar.
\end{abstract}

\section{Kata Kunci : Sikat Gigi, Anak TK}

\begin{abstract}
Ar-Raafi Kindergarten School in Tambang District is one of the kindergartens in Kampar. Based on the data obtained, there are several obstacles faced by Kindergarten Ar-Raafi in upholding the discipline of the school community, especially students in implementing eight clean and healthy lifestyles at school, including brushing their teeth properly and correctly. Currently, in carrying out the program, its academic activities have not been fully supported by activities that lead to improving the skills and attitudes of students, including the not maximizing the reach of extracurricular education which will provide added value for students. The preliminary data showed that the description of clean living behavior for students was still considered sufficient. We all know that schools as a place for students to gain knowledge need to develop activities based on academic abilities and soft skills that support learning activities. The training "Brushing the teeth properly and correctly at Kindergarten ArRaafi" can increase knowledge about how to brush teeth properly. Increased knowledge and skills for the trainees on how to brush their teeth properly by means of lectures and demonstrations. It is hoped that the empowerment of teachers in monitoring tooth brushing can be realized well by providing several examples of how to properly brush teeth.
\end{abstract}

Keywords: Tooth brush, Kindergarten children

\section{PENDAHULUAN}

Perguruan Tinggi sebagai lembaga penyelenggaraan pendidikan tinggi yang menghimpun mahasiswa sebagai peserta didik di dalamnya, memiliki tanggung jawab moral dalam menciptakan suatu kondisi yang dinamis bagi berlangsungnya suasana kondusif di kehidupan masyarakat. Perguruan tinggi sebagai tempat berlangsungnya "Learning process" berfungsi juga sebagai wahana pembentukan pribadi mahasiswa sebagai "agent of change" dan "agent of social control" di tengah-tengah masyarakat. Sehingga perguruan tinggi selayaknya tidak hanya menyelenggarakan kegiatan akademis di ruang perkuliahan semata, namun lebih dari itu, perguruan tinggi juga diharapkan mampu melahirkan insan-insan intelektual yang selain 
berwawasan luas dan visioner, juga memiliki kepekaan terhadap kondisi sosial masyarakat (Civil of Responsibility).

Dalam hubungannya dengan masyarakat termasuk di dalamnya adalah upaya meningkatkan derajat kesehatan kelompok anak usia sekolah melalui upaya hidup bersih dan sehat yang diselenggarakan dengan penyelenggaraan usaha kesehatan sekolah untuk meningkatkan kemampuan hidup sehat peserta didik dalam lingkungan hidup sehat sehingga peserta didik dapat belajar, tumbuh dan berkembang secara harmonis dan optimal sehingga diharapkan dapat menjadi sumber daya manusia yang berkualitas.

TK Ar- Raafi adalah salah satu sekolah Taman Kanak-kanak dan Penitipan Anak yang letaknya berada di Kecamatan Tambang dan sudah bertahun-tahun menyelenggarakan kegiatan akademis dalam membantu masyarakat menimba ilmu di sekolah tersebut. Keberadaan sekolah ini berdampak sangat positif bagi peserta didik mendapatkan pengetahuan yang baik dan berkualitas. Apalagi bila didukung oleh kegiatan ekstrakulikuler yang menambah wawasan bagi peserta didik. Kemampuan yang disalurkan bagi mereka akan berdampak terhadap perilaku hidup bersih dan sehat bagi peserta didik. Tentunya masyarakat akan merasa nyaman bila anak-anaknya selain mendapatkan pengetahuan, keterampilan juga mendapatkan nilai tambah bagi dari segi kualitas dan kuantitas.

Program Usaha Kesehatan Sekolah (UKS) merupakan tanggungjawab bersama baik dari dinas kesehatan, dinas pendidikan, departemen agama dan departemen dalam negeri sehingga dengan keterlibatan semua pihak dapat terwujud generasi penerus yang sehat secara fisik dan mental. Untuk menunjang proses pembelajaran yang kondusif, maka siswa-siswi harus mengerti dan menerapkan cara mencuci tanga yang benar dalam kehidupan sehari-hari.

\section{METODE}

Metode pelaksanaan pada program pengabdian kepada masyarakat ini disusun secara sistematis:

3.1. Tahap Persiapan

Kegiatan yang dilakukan pada tahap persiapan adalah :

a. Survei tempat pelaksanaan kegiatan

b. Pengurusan administrasi dan perijinan tempat pengabdian masyarakat

c. Persiapan materi edukasi dan promosi cara menggosok gigi yang benar

3.2. Tahap Pelaksanaan Kegiatan

Kegiatan pengabdian akan dilakukan setelah persiapan dan perizinan selesai. Kegiatan akan dilakukan di TK Ar-Raafi Kabupaten Kampar. Dalam pelaksanaannya sasaran dijelaskan tentang mencuci tangan yang benar, manfaat, cara, alat-alat yang digunakan serta kapan waktu menggosok gigi yang baik dan benar. Selanjutnya mempraktikkan cara menggosok gigi yang benar dan meminta peserta didik melakukan sesuai yang telah diajarkan.

3.3. Pembuatan Artikel Pengabdian

Artikel pengabdian dibuat sebagai bentuk hasil akhir dari kegiatan pengabdian yang telah dilakukan agar nantinya manfaat dari pengabdian ini benar-benar tercapai.

3.4 Tahap Evaluasi

Tahap evaluasi merupakan tahapan yang dilakukan untuk menilai kegiatan secara keseluruhan dan meninjau kembali apakah terdapat kekurangan-kekurangan selama kegiatan. Tahap evaluasi ini bertujuan agar kegiatan yang dilakukan dapat berjalan dengan efektif dan sesuai dengan yang diharapkan. Tahap evaluasi difokuskan terhadap kemampuan peserta didik menerapkan cara menggosok gigi yang benar.

3.5 Tahap Pembuatan Laporan

Pembuatan laporan disesuaikan dengan hasil yang telah dicapai selama melakukan kegiatan pengabdian kepada masyarakat.

\section{HASIL DAN PEMBAHASAN}

HASIL 
Hasil pelaksanaan kegiatan pengabdian dapat diuraikan melalui 2 (dua) tahapan kegiatan, yaitu persiapan dan pelaksanaan. Pada tahap persiapan yang merupakan perencanaan program pengabdian dilakukan kegiatan sebagai berikut :

1. Koordinasi dengan pihak TK Ar-Raafi

Koordinasi dengan pihak Sekolah dilakukan dengan Kepala TK Ar-Raafi. Pihak sekolah menerima dan mendukung kegiatan pengabdian yang dilakukan oleh Tim Pengabdi dalam rangka memantau status kesehatan Balita yang ada di TK Ar-Raafi.

2. Penetapan waktu pelatihan

Pelaksanaan pelatihan berdasarkan kesepakatan dengan Kepala TK Ar-Raafi yang dilakukan pada hari Jum'at, tanggal 24 Juli 2020.

3. Penentuan sasaran dan target peserta pelatihan

Dari koordinasi Kepala TK Ar-Raafi maka sasaran pelatihan adalah guru dan pengasuh TK Ar-Raafi, yaitu dengan target peserta pelatihan sebanyak 6 orang.

4. Perencanaan materi pelatihan

Materi pelatihan yang telah direncanakan oleh tim pengabdi meliputi pengetahuan tentang pentingnya Sikat gigi, cara sikat gigi yang baik dan benar, waktu sikat gigi.

Tahapan persiapan di atas selanjutnya diikuti dengan tahap pelaksanaan. Pada tahap pelaksanaan program pengabdian dapat diuraikan bahwa:

1. Kegiatan pengabdian "Sikat gigi" dilaksanakan pada hari Jumat, tanggal 24 Juli 2020, di TK Ar-Raafi.

2. Kegiatan pengabdian dihadiri oleh 16 orang peserta yang diundang berdasarkan arahan dari Kepala TK Ar-Raafi.

3. Para peserta cukup senang dan antusias dengan adanya program pengabdian dari tim PPM FIK UP berupa pelatihan cuci tangan di TK Ar-Raafi.

4. Materi pelatihan berupa: (a) pengetahuan pentingnya Gosok gigi, (b) gosok gigi yang benar,(c) akibat jika tidak gosok gigi.

5. Pada sesi tanya jawab ada beberapa pertanyaan yang diajukan peserta, antara lain: kapan saja gosok gigi dapat dilakukan.

6. Dalam kegiatan pelatihan diberikan contoh cara gosok gigi yang benar.

\section{PEMBAHASAN} berikut:

Hasil pelaksanaan kegiatan PPM secara garis besar dapat dilihat berdasarkan komponen sebagai

1. Keberhasilan target jumlah peserta pelatihan

Keberhasilan target jumlah peserta pelatihan dapat dikatakan sangat baik. Dari 6 orang peserta yang diundang berdasarkan arahan Kepala TK Ar-Raafi (100\%) dapat menghadiri kegiatan pelatihan.

2. Ketercapaian tujuan pelatihan

Ketercapaian tujuan pelatihan dapat dikatakan baik (80\%). Ada peningkatan pengetahuan dari peserta tentang pentingnya sikat gigi yang baik dan benar sehingga peserta bisa kedepannya mengetahui setiap kegiatan peserta didik mengutamakan sikat gigi untuk kebersihan mereka.

3. Ketercapaian target materi yang telah direncanakan

Ketercapaian target materi yang telah direncanakan dapat dikatakan baik (80\%). Semua materi pelatihan dapat disampaikan oleh tim pengabdi dengan waktu yang terbatas. Materi yang telah disampaikan : (a) pengetahuan pentingnya gosok gigi, (b) gosok gigi yang benar,(c) akibat jika tidak gosok gigi. Semua materi tersebut dapat disampaikan oleh tim pengabdi dengan waktu yang sudah ditentukan.

4. Kemampuan peserta dalam penguasaan materi

Kemampuan peserta dalam penguasaan materi dapat dikatakan baik (75\%). Penyampaian materi dengan metode ceramah dan demonstrasi mendukung kemampuan peserta dalam menguasai materi yang disampaikan oleh tim pengabdi.

Secara keseluruhan kegiatan pelatihan "Gosok Gigi yang baik dan benar" di TK Ar-Raafi dapat dikatakan baik dan berhasil, yang dapat diukur dari keempat komponen di atas. 


\section{SIMPULAN}

1. Pelatihan "Gosok Gigi yang baik dan benar" di TK Ar-Raafi" dapat meningkatkan pengetahuan tentang Cara gosok gigi yang benar.

2. Peningkatan pengetahuan dan keterampilan bagi peserta pelatihan tentang cara gosok gigi benar dilakukan dengan metode ceramah dan demonstrasi.

3. Pemberdayaan guru dalam pemantauan gosok gigi diharapkan dapat terwujud dengan baik dengan adanya pemberian beberapa contoh cara gosok gigi yang benar.

\section{UCAPAN TERIMA KASIH}

Pengabdi mengucapkan terimakasih kepada TK Ar- Raafi sebagai mitra pengabdian Masyarakat yang sudah bersedia berkerjasama dalam pelaksanaan pengabdian kepada masyarakat ini.

\section{DAFTAR PUSTAKA}

Aiello. (2008). Effect of Hand Hygiene on Infectious Disease Risk in the Community Setting: A MetaAnalysis. American Journal of Public Health 2008, 98 (8):1372-1381

Burton, M., Cobb, E., G,Curtis, V Donachie, P., Judah., Schmidit, W. 2011. The eff ect of handswashing with water or soap on bacterial contamination of hands. Int. J. Environ. Res. Public Health, 8, 97-104. doi:10.3390/ijerph8010097

Desiyanto., \& Djannah.2013.Efektifitas Mencuci Tangan Menggunakan Cairan Pembersih Tangan Antiseptik (Hand Sanitizer) Terhadap Jumlah Angka Kuman, Jurnal Kesehatan Masyarakat,Vol.2 No.2.

Departemen Kesehatan RI. (2009). Panduan Penyelenggaraan Cuci Tangan Pakai Sabun Sedunia (HCTPS). Jakarta

Undang-Undang Republik Indonesia No. 36 tahun 2009 tentang Kesehatan

WHO. (2009). Guidelines on Hand Hygiene in Healthcare. Geneva: WHO.

Zuraidah, Y. 2013. Hubungan Pengetahuan dan Sikap Dengan Perilaku Mencuci Tangan Dengan Benar Pada Siswa SD Kota Lubuklinggau Tahun 2013. Jurnal fakultas keperawatan. Politeknik Kesehatan Palembang 